\title{
IMPROVEMENT OF EFFECTIVENESS OF PRODUCTS PLACING AND DISPATCH IN THE DISPATCH WAREHOUSE OF THE ROUGH ROLLING PLANT
}

\author{
Marek Šafránek \\ VSB - Technical University of Ostrava, Ostrava, Czech Republic, \\ marek.safranek.st@vsb.cz (corresponding author) \\ Andrea Sikorová \\ VSB - Technical University of Ostrava, Ostrava, Czech Republic, \\ andrea.sikorova@vsb.cz
}

Keywords: logistics, management, warehouse, Pareto analysis

Abstract: The paper describes a metallurgical enterprise and its production plants, including assortment of the manufactured products. The paper continues by the system of placing these products into a dispatch warehouse of the rough rolling plant, describes its benefits and disadvantages in connection with another processes. It also contains several alternatives of products disposition in warehouse with regards to certain criteria, as well as reasons why the enterprise should place emphasis on a correct lay-out of the products, which will lead to the grow of the effectiveness of placing and dispatch of the products and - by this - to the decrease of the total costs of the enterprise.

\section{Introduction}

As far as the company wants to be successful and competitive, it must approach systematically to the logistics management and to control particular activities as comprehensive processes. The main aim of the logistics management is the maximal satisfaction of all customer's requirements with the required quality, in agreed time and with the minimal costs.

The first part of the paper presents a metallurgical enterprise and contains a description of its production plants and all manufactured assortment of the rough rolling plant and the dispatch warehouse where these items are stored and also processed.

The second part of the paper deals with the system of placing the products in the dispatch warehouse of the rough rolling plant. Proposals of placing with the use of professional literature are here also discussed.

Consequently, a Pareto analysis is worked out, also known as an 80/20 rule, which identifies the most significant products manufactured and placed in the dispatch warehouse of the rough rolling plant. These products are afterwards divided into groups and sub-groups and consequently - based on the, "ABC" and ,XYZ“" analyses - the most suitable placement of these products in the warehouse is selected with respect to the optimization of the dispatch process.

The last part is engaged in evaluation of the proposal of the disposition of the products, which will cause the growth of the processes effectiveness, mainly by means of decreasing the manipulation times of the cranes and the searching time of particular products.

\section{Metallurgical enterprise}

The manufacturing activity of the enterprise is mainly focused on the production of machine parts, steel structures, engineering investment complexes and production lines, operating cylinders, castings, wheel sets and axles. A part of the enterprise is also a heat processing shop and an electric motors repair shop. Enterprise

is preferably focused on the metallurgical industry, but it also can satisfy needs of the customers dealing in the petrochemical, mining, machine engineering, building, automotive, etc. industries. The annual manufacturing capacity exceeds 3 mil. tons of steel. The enterprise exports its products to more than 60 countries across the world.

The entire enterprise consists of several production plants. Particular plants produce a wide spectrum of products and also provide all sorts of services. These are Cocking Plant, High Furnaces, Steel Plant and Rolling Plant. The Rolling Plant consists of Rough Rolling Plant, Continuous Wire Rolling Mill, Band Mill P1500 and Medium and Fine Rolling Plant. This plant manufactures long flat products which are being used for constructions and structures, for example, structures of high-voltage columns.

The Rough Rolling Plant this paper is focused to, called also the HCC Rolling Plant, manufactures rough sectional steel, starting from separate circular rods, through shaped steel (profiles of L, V, I, U etc. types) and also special steel profiles. Profiles of steel armatures and flat steel are also manufactured here. The profiles are placed in the dispatch warehouse of the Rough Rolling Plant, where other modifying operations are also performed [1-3]. 


\section{Products placing system}

Random organization of the warehouse is one of the easiest types of storing we know of. Very simplistically, it is a system of random storing, when different stored items are placed to the nearest free places which are currently available $[4,5]$.

The procedure of proposing a lay-out of the storage area is not easy, because it is necessary to estimate how many products and of which type will be stored by the enterprise. Especially difficult is to sketch out the warehouse area in regard to big companies with a wide assortment of products. After that it is necessary to lay-out the warehouse area and propose alternative possibilities of solution, from which only one solution best meeting conditions of effectiveness will be selected [6].

As far as the stored products are concerned, the warehouse can be organized with respect of several following criteria [7]:

- products with high turnover rate are situated as close as possible to the main dispatch place,

- products with slow turnover rate are situated in the most distant places in the warehouse,

- other area is determined for such products which come into the warehouse regularly, or for such products which requires performing other operations (modifications or processing) prior to the dispatch.

- $\quad$ storage premises should be configured with regards to the speed of selling as well as to the difference of sizes and types of the stored products.

Provided the enterprise observes a correct lay-out of the warehouse, of its areas and stored products, the total costs will be, thus, decreased. There are five main reasons for the correct lay-out of the warehouse, and that is the growth of the outputs, improvement of the flow of products, the decrease of the costs, improvement of customer's service, and the provision of better conditions for employees [8].

\section{Pareto analysis}

The Pareto principle (also known as the 80/20 rule) should be used by each organization which wishes to increase its effectiveness and satisfaction. It can multiply company's profitability and improve quality of the total services, while decreasing the costs. The $80 / 20$ rule asserts that a minority of causes, inputs or endeavours usually leads to a majority of results, outputs or successfulness. For example, 80 percent of outputs is the result of 20 percent of inputs, or 20 percent of products brings 80 percent of the turnover [9].

The $80 / 20$ rule can be also applied to the assortment of the manufactured products - see Figure 1, where you can see products manufactured by the metallurgical enterprise in one of its production plants in 2017. The most manufactured item is so called V-Profiles (the V-Profiles are most frequently used for the construction of highvoltage columns), which have more than a $60 \%$ share in the all manufactured assortment placed in the dispatch warehouse of the Rough Rolling Plant. A smaller quantity of P-Profiles (flat shapes) and U-Profiles is manufactured. These 3 types together (V, P, U Profiles) create $80 \%$ of all items placed in the dispatch warehouse. The output of the Pareto diagram is, thus, the identification of the most significant items (items with the highest turnover rate) of the dispatch warehouse.

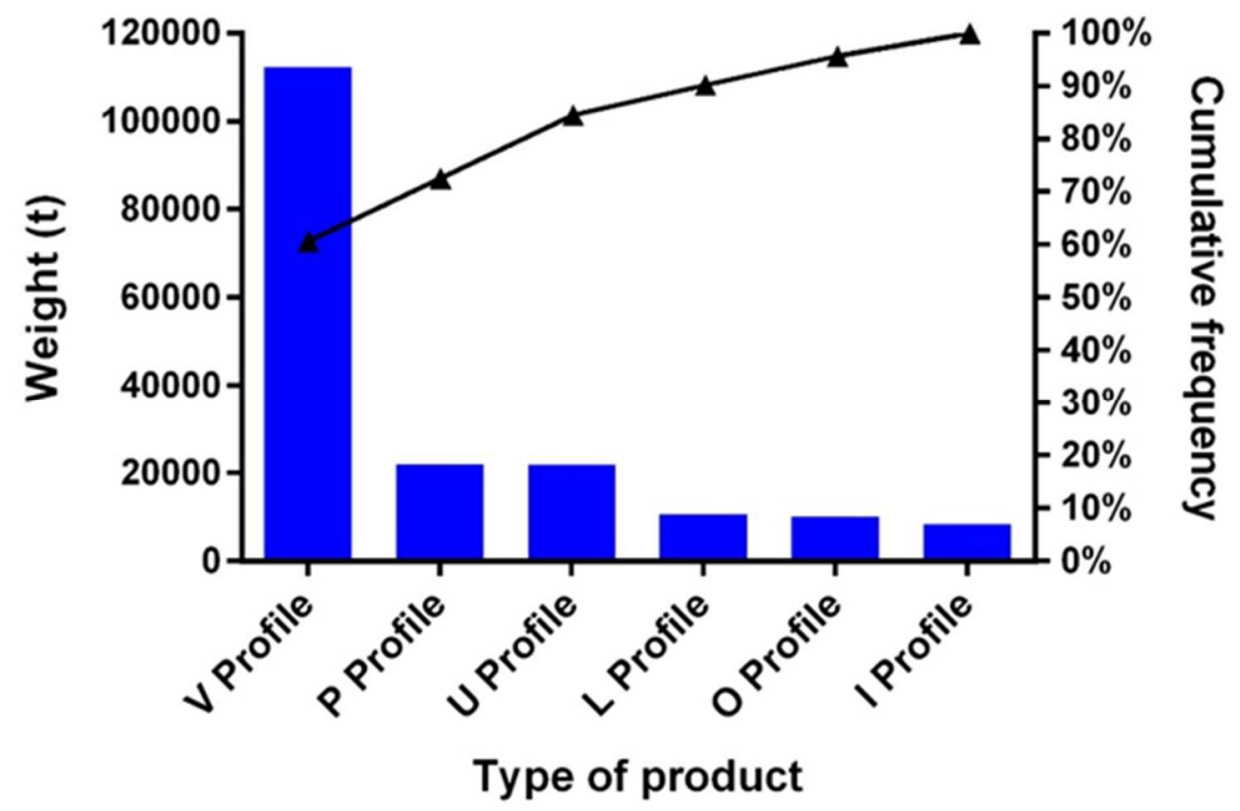

Figure 1 Overall share of particular products in 2017 - Pareto analysis 


\section{Division of products into groups}

\subsection{ABC analysis}

Based on the data obtained from the statement of balances of the dispatch warehouse, a quantity of the manufactured products was determined (see Table 1), and these products were consequently divided into groups depending on the frequency of production. The "Group A" contains products with the highest frequency of production
(V-profile), which create more than $60 \%$ of the total quantity of the products placed in the dispatch warehouse in 2017. The "Group B" consists of P and U Profiles. These products, however, create just more than $23.5 \%$. The products included in the "Group C" has the lowest frequency of production. This Group consists of three types of profiles (I, O, L) and takes almost $16 \%$ of the total quantity of the stored products in the given year.

Table 1 Division of the products into groups depending on the frequency of their production

\begin{tabular}{|c|c|r|c|c|}
\hline \multirow{2}{*}{ Group } & Product type & Quantity (t) & Frequency (\%) & Cumulated (\%) \\
\hline \multirow{3}{*}{ C } & I-Profiles & $8,352.4$ & 4.5 & 4.5 \\
\cline { 2 - 5 } & O-Profiles & $10,139.0$ & 5.5 & 10.0 \\
\cline { 2 - 5 } & L-Profiles & $10,528.7$ & 5.7 & 15.7 \\
\hline \multirow{2}{*}{ B } & U-Profiles & $21,876.4$ & 11.8 & 27.5 \\
\cline { 2 - 5 } & P-Profiles & $21,942.6$ & 11.9 & 39.4 \\
\hline \hline \multirow{2}{*}{$\mathbf{A}$} & V-Profiles & $112,297.5$ & 60.7 & 100.0 \\
\hline
\end{tabular}

\subsection{Division of the warehouse into zones on the basis of the "ABC analysis"}

\section{Group A}

The main principle is that the products of the "Group A", which are the most significant for the company from the point of view of the frequency of production, are situated in the place, which is the nearest to the loading platform - see Figure 2. This place is strategically important because bunches of products weighing few tons will be loaded (dispatched) quicker if they are situated in this area. Due to shorter distances which must be traveled by cranes with the products in the premises of the warehouse, the manipulation times will be shortened. The cranes, consequently, will be freer for another possible operation in the warehouse.

\section{Group B}

The products of the Group B have an ordinary meaning for the company from the point of view of their frequency, that's why they are situated in the warehouse in a place, which is neither in the nearest nor in the farthest distance to the loading platform. The dispatch of these products is not so frequent as the dispatch of the products of the Group A.

\section{Group C}

On the contrary, the least important products for the enterprise from the point of view of frequency are the products of "Group C", which are placed in the most distant part of the warehouse from the loading platform. The cranes have to travel the biggest distances for the products from this group. With regards to the lowest number of stored products of this group, the time loss is, thus, the lowest.

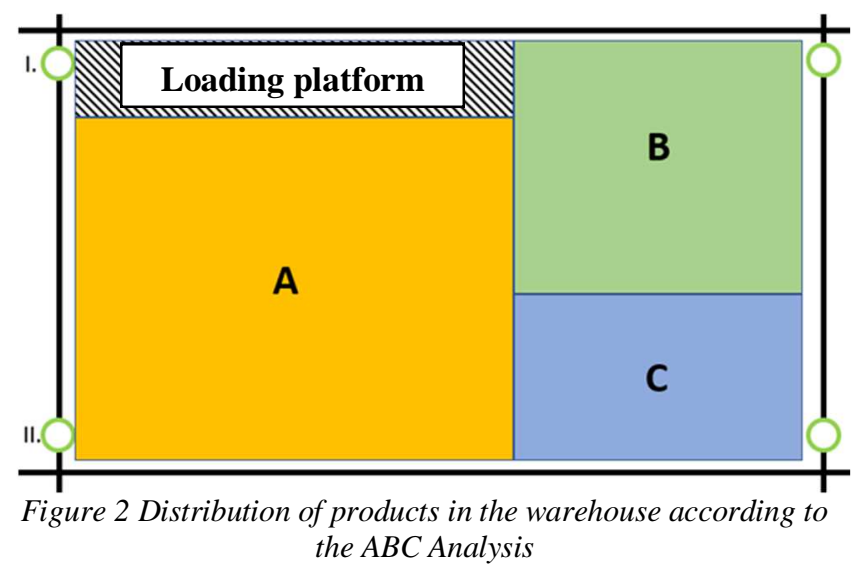

\subsection{XYZ Analysis of the products of Group A}

This analysis deals with the distribution of the products of Group A (the most significant products for the enterprise from the point of view of frequency) into sub-groups of $X$, $\mathrm{Y}, \mathrm{Z}$ depending on their turnover rate. The XYZ Analysis is applied with a sample of the products in the I. quarter of 2017. The used data were obtained from the statements of balances of the dispatch warehouse of the metallurgical enterprise. The Group X contains products with the lowest turnover rate, the Group $Y$ - products with the average turnover rate, and Group $\mathrm{Z}$ - products with the highest turnover rate. Table 2 shows distribution of particular types of V-Profiles depending on their sizes and quantity. 
IMPROVEMENT OF EFFECTIVENESS OF PRODUCTS PLACING AND DISPATCH IN THE DISPATCH WAREHOUSE OF THE ROUGH ROLLING PLANT

Marek Šafránek; Andrea Sikorová

Table 2 Distribution of the products into groups depending on their turnover rate

\begin{tabular}{|c|c|c|}
\hline Group & Size (mm) & Quantity (t) \\
\hline \multirow{4}{*}{$\mathbf{X}$} & $80 \times 80$ & 732.4 \\
\cline { 2 - 3 } & $140 \times 140$ & 716.3 \\
\cline { 2 - 3 } & $90 \times 90$ & 572.8 \\
\cline { 2 - 3 } & & 2021.5 \\
\hline \multirow{4}{*}{$\mathbf{Y}$} & $130 \times 130$ & 1072.5 \\
\cline { 2 - 3 } & $110 \times 110$ & 1610.4 \\
\cline { 2 - 3 } & & 2682.9 \\
\hline \multirow{4}{*}{$\mathbf{Z}$} & $150 \times 150$ & 2902.3 \\
\cline { 2 - 3 } & $120 \times 120$ & 3434.8 \\
\cline { 2 - 3 } & $100 \times 100$ & 4837.1 \\
\cline { 2 - 3 } & & $\mathbf{1 1 1 7 4 . 2}$ \\
\hline
\end{tabular}

The division of the products of Group A into subgroups in dependence on their turnover rate makes it possible to determine more detailed distribution of these products for even bigger acceleration of the dispatch time. Whereas, the product with the highest turnover rate fall into Group $\mathrm{Z}$ will be situated as close as possible to the loading platform - see Figure 3, products of Group Y directly behind them, and, in the end, the products with the lowest turnover rate of Group $\mathrm{X}$ - farthest from the loading platform.

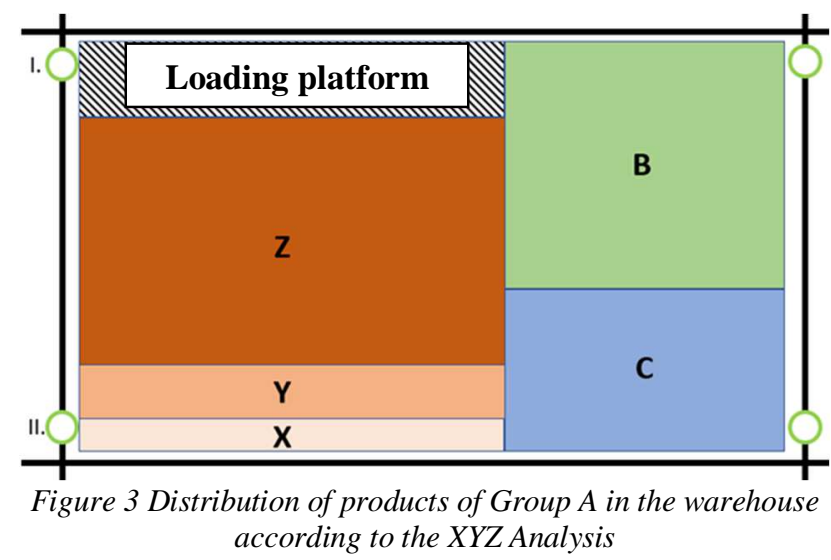

\section{Final recommendations, evaluation and conclusion}

According to the internal interviews with employees of the enterprise and the results of the Pareto Analysis, it is necessary to pay attention especially to the disposition of the V-type profiles. This type of profiles takes the biggest share of the manufactured products, namely more than $60 \%$.

The ABC Analysis was consequently performed and became a base for the decision about dividing the products into groups from the point of view of the frequency of production, and further proposition of the lay-out of the warehouse according to separate groups of the productions. The proposition of the warehouse was performed so that separate groups of the products were placed on strategically the most beneficial positions of the warehouse with regards to the decrease of the manipulation times of the cranes.

The lay-out of the warehouse area in dependence on the turnover rates for the products of Group A.

One of the possible form of the rules for the optimization of the operation of the warehouse and acceleration of dispatching is the determination of storing places in accordance with the turnover rates of the products. This proposal comes from data of the manufactured profiles in 2017 and the XYZ Analysis, which was carried out with the products of Group A. The products of this group were divided into three groups in dependence on the turnover rate and a position in the warehouse was consequently assigned. The products of Group $\mathrm{Z}$ with the highest turnover rate are placed as close as possible to the loading platform so that the orders consisted of these products can be dispatched as quickly as possible and so that loading times were shortened and process as a whole was optimized.

This proposal however has one difficulty. The enterprise manufactures a wide portfolio of products of all sorts of sizes. Neither the enterprise itself know what will be produced in the next month. This disadvantage however can be solved, for example, by implementation of more detailed visualization of the warehouse, where it will be possible to effectively propose a lay-out of the profiles in accordance with particular sizes with help of a sufficient software.

\section{Acknowledgements}

The work was supported by the specific university research of the Ministry of Education, Youth and Sports of the Czech Republic in VSB - Technical University of Ostrava No. SP2017/67 and SP2018/107.

\section{References}

[1] ArcelorMittal, www.arcelormittal.cz: Production plants of the enterprise, [Online], Available: http://ostrava.arcelormittal.com/ospolecnosti/zavody.aspx [12 Apr 2018].

[2] ArcelorMittal, www.arcelormittal.cz: Enterprise profile, [Online], Available: http://ostrava.arcelormitta 1.com/o-spolecnosti/o-spolecnosti.aspx [24 Apr 2018].

[3] ArcelorMittal, www.arcelormittal.cz: Enterprise history, [Online], Available: http://ostrava.arcelormitta l.com/o-spolecnosti/historie-spolecnosti.aspx [11 May 2018].

[4] MACUROVÁ, P., KLABUSAYOVÁ, N., TVRDOŇ, L.: Logistics, Ostrava, VŠB-TU Ostrava, 2014. 
[5] SIXTA, J., MAČÁT, V.: Logistics: theory and practice, Brno, CP Books, Business books (CP Books), 2005.

[6] SATISH, K. K., PURVA, K.: Basics of distribution management: a logistical approach, Eastern economy ed. New Delhi, Prentice-Hall of India, 2003.

[7] LAMBERT, D. M., STOCK, J. R., ELLRAM L. M.: Logistika: příkladové studie, řizení zásob, přeprava a skladování, balení zboží, $2^{\text {nd }}$ ed., Brno, CP Books, Business books (CP Books), 2005. (Original in Czech)

[8] OWENS, G., MANN, R.: Materials Handling System Design, The Distribution Handbook, ed. James F. Robeson; William C. Copacino (New York: Free Press,
1994). Převzato z LAMBERT, Douglas M.; STOCK, James R.; ELLRAM, Lisa M. Logistika. $2^{\text {nd }}$ ed., Brno: CP Books, 2005.

[9] KOCH, R.: Pravidlo 80/20: umění dosáhnout co nejlepších výsledků s co nejmenším úsilím. 3. aktualiz. vyd. Praha, Management Press, 2015. (Original in Czech)

\section{Review process}

Single-blind peer review process. 